\title{
In vitro antioxidant activity and qualitative phytochemical analysis of two Vismia (Hypericaceae) species collected in Los Andes, Venezuela
}

\author{
Alexis Buitrago D. ${ }^{1,2}$, Janne Rojas-Vera $^{1 *} \&$ Yonel Peñaloza ${ }^{2}$ \\ 1. "Biomoléculas Orgánicas" research group, Research Institute, Faculty of Pharmacy and Bioanalysis, University of \\ Los Andes, Mérida 5101, Venezuela; alexisb@ula.ve, janner@ula.ve \\ 2. Analysis and Control Department. Faculty of Pharmacy and Bioanalysis, University of Los Andes, Mérida 5101, \\ Venezuela; yonelp@ula.ve
}

Received 08-II-2016. C Corrected 20-VI-2016. Accepted 27-VII-2016.

\begin{abstract}
Vismia genus is distributed mainly in tropical and subtropical regions of Central, South America and some areas of Africa. According to previous investigations, antioxidant potential of Vismia species might be related to anthrones, anthraquinones, flavonoids and phenol derivatives biosynthesized by these plants. In this investigation, phytochemical screening of Vismia baccifera (VB) from Mérida-Venezuela and Vismia macrophylla (VM) from Táchira-Venezuela methanolic extracts, carried out using various chemical assays, revealed an abundant presence of anthraquinones in both species analyzed. Glycosides were also present while flavones and dehydroflavones were observed abundantly in VB but moderated in VM. Triterpenes were also detected and steroids showed to be abundant in VM but moderate in VB. On the other hand, antioxidant capacity measured by the DPPH assay showed that VM possesses a stronger antioxidant activity than VB with $\mathrm{IC}_{50} 5.50 \mu \mathrm{g} \mathrm{mL} \mathrm{mL}^{-1}$. Phenol and flavonoid assays carried out by Folin-Ciocalteu and colorimetric test also revealed that methanol extracts of both species contain high concentrations of these metabolites. A relationship between the antioxidant activity, total phenol and flavonoids content of the extracts analyzed was demonstrated in this investigation since those samples with higher phenolic concentrations showed likewise higher antioxidant activity. Rev. Biol. Trop. 64 (4): 1431-1439. Epub 2016 December 01.
\end{abstract}

Key words: antioxidant activity, DPPH, total phenolic content, total flavonoids content, qualitative phytochemical analysis, Vismia baccifera, Vismia macrophylla.

Free radicals such as superoxide ions, hydrogen peroxide and hydroxyl radicals are highly reactive species generated from normal oxygen metabolism as well as different exogenous factors (Parajuli, Pun, Parajuli, \& Jamarkattel-Pandit, 2012) and biochemical reactions from human organisms (Álvarez et al., 2008). Radicals accumulation may lead to oxidative stress in cells and promote several pathologies such as cancer, diabetes mellitus, hepatic ailments, inflammation, premature aging, among others (Sarabjot \& Poonam, 2014). Recently, the search for natural antioxidants that might prevent these degenerative diseases has attracted the attention of researchers; as a result, a number of investigations have revealed that such diseases may be prevented by a proper intake of antioxidants (Shah \& Hossain, 2014; Hossain \& Shah, 2015). Furthermore, plant extracts have revealed to be a major source of chemical compounds with high antioxidant activity (Lizcano, Fadil-Bakkali, Ruiz-Larrea, \& Ruiz-Sanz, 2010; Baydar, Özkan, \& Yasar, 2007; Tepe \& Sokmen, 2007).

Vismia genus (Hypericaceae) comprises approximately 55 species, distributed mainly in tropical and subtropical regions of Central and South America (Botta, Delle-Monache, Delle-Monache, Marini-Bettolo, \& Menichini, 1986). Many of these species have been 
used in traditional medicine to treat wounds, ulcerations, herpes, as antifungal, purgative and febrifuge (Nagem \& Oliveira, 1997; Fuller, Westergaard, Collins, Cardellina, \& Boyd, 1999). Recent investigations have proved the antioxidant potential of $V$. ferruginea and $V$. baccifera extracts, and the results have indicated that this activity may be related to chemical compounds biosynthesized by these plants (Álvarez et al., 2008). According to previous investigations, Vismia species are composed mainly by anthrones, anthraquinones, flavonoids and phenol derivatives that might be related to the antioxidant activity shown by these species (Vizcaya, Morales, Rojas, \& Nuñez, 2012). On the other hand, xanthone and its derivatives, present in large amounts in Vismia species, seem to be very important since these kind of secondary metabolites have also demonstrated that possesses antidepressant, antimicrobial, antiviral, cytotoxic and cardiotonic activities (Hussain et al., 2012; Lizcano et al., 2015). Nowadays, there is a high interest for the search of natural sources to prevent oxidative stress, thus, results obtained are considered as a contribution to the natural products investigation. The aim of the present investigation was to evaluate the free radical scavenging capacity, total phenolic and flavonoids content as well as the qualitative phytochemical screening of methanol extracts obtained from $V$. macrophylla (VM) and $V$. baccifera (VB) collected in Táchira and Mérida state, Venezuela.

\section{MATERIALS AND METHODS}

Plant material: V. macrophylla Kunth was collected from Michelena, Táchira State, at 1200 masl (7 $\left.56^{\prime} 30^{\prime \prime} \mathrm{N}-72^{\circ} 14^{\prime} 33^{\prime \prime} \mathrm{W}\right)$ and $V$. baccifera L. Triana \& Planch was harvested from La Hechicera, Mérida State at 1800 masl (83' $\left.41^{\prime \prime} \mathrm{N}-71^{\circ} 09^{\prime} 34^{\prime \prime} \mathrm{W}\right)$. Both species were collected in February 2015, during rainy season and flowering stage. Botanical identification was carried out by Dr. Pablo Meléndez, MERF Herbarium, Faculty of Pharmacy and Bioanalysis, University of Los Andes, Mérida,
Venezuela. Voucher specimens were deposited under the following codes: VM-JR39 and VB-JR25.

Extraction: Leaves of both species were placed into an oven at $45^{\circ} \mathrm{C}$ for three days. Dry material was ground in a mill and then weighed, $V$. macrophylla (1 $850 \mathrm{~g} \mathrm{VM}$ ) and $V$. baccifera (1 $650 \mathrm{~g} \mathrm{VB}$ ). Room temperature methanol extraction (four L, Sigma-Aldrich, anhydrous $99.8 \%$ ) was carried out with both species under investigation for five days, changing the solvent for fresh and leaving the extraction for another five days with same plant material to achieve an exhaustive extraction. Extracts were concentrated to dryness by using a rotaevaporator under reduced pressure; weights of concentrated dried extracts were also measured $(250 \mathrm{~g}$ $\mathrm{VM}$ and $200 \mathrm{~g} \mathrm{VB}$ ).

Liquid-liquid extracts fractionation: Methanol extracts of VM and VB were subjected to liquid-liquid fractionation using the following solvents: hexane (one L, SigmaAldrich, anhydrous $95.0 \%$ ), dichloromethane (one L, Sigma-Aldrich, anhydrous $99.8 \%$ ), ethyl acetate (one L, Sigma-Aldrich, anhydrous $99.8 \%$ ), and butanol (one L, Sigma-Aldrich, anhydrous $99.8 \%$ ). A volume of $500 \mathrm{~mL}$ of distilled water were added to each extract in a separation funnel of one liter capacity, and three consecutive extractions were conducted for every single solvent by increasing polarity. All samples were concentrated in a rotaevaporator to dryness and then weighed; hexane (34 g VM; 40 g VB), dicholoromethane (10 g VM; $22 \mathrm{~g} \mathrm{VB})$, ethyl acetate (39 g VM; $30 \mathrm{~g} \mathrm{VB})$, butanol (65 g VM; $40 \mathrm{~g} \mathrm{VB}$ ) and water (50 g $\mathrm{VM} ; 45 \mathrm{~g} \mathrm{VB})$. Concentrated extracts were maintained in the dark at four ${ }^{\circ} \mathrm{C}$ until antioxidant activity performance evaluation.

Phytochemical screening: Methanol extracts of VM and VB were evaluated to determine the presence of chemical constituents using standard procedures. A blank sample containing only the reagents, according to the test conducted, was prepared in order to compare to the main reaction. Every procedure is described below: 
Testing for alkaloids: Each extract $(10$ $\mathrm{mg}$ ) was dissolved in $2 \mathrm{~mL}$ of $5 \%$ hydrochloric acid; after mixing and filtering by gravity, three aliquots were taken. Drops of Wagner, Mayer and Dragendorff reagents were added to each. A red-brown precipitate (Wagner), white precipitate (Mayer) and red-orange precipitate (Dragendorff) indicated the presence of such metabolites (Tiwari, Kumar, Kaur, Kaur, \& Kaur, 2011).

Testing for coumarins: A $10 \mathrm{mg}$ amount of each sample were added to $0.5 \mathrm{~mL}$ of ethanol along with two drops of ammonium hydroxide $8.23 \mathrm{M}$. If examination under UV light at a wavelength of $365 \mathrm{~nm}$ shows the presence of blue or green fluorescence, it might be indicative of a positive result (Trease \& Evans, 2002).

Testing for glycosides: A $10 \mathrm{mg}$ amount of each extract were dissolved in $1 \mathrm{~mL}$ of distilled water followed by five drops of aqueous sodium hydroxide $2.5 \mathrm{M}$. A yellow colour indicated a positive reaction (Shyamala-Gowri \& Vasantha, 2010).

\section{Testing for cardiotonic glycosides:} (Tiwari et al., 2011)

Keller-Killiani reaction: A $10 \mathrm{mg}$ amount of each extract were dissolved in Keller's reagent and five drops of sulfuric acid $18 \mathrm{M}$. The occurrence of a brown ring between the two phases formed is indicative of deoxy glycosides.

Legal reaction: three drops of pyridine, one drop of $5 \%$ sodium nitroprusside aqueous solution and three drops of $2 \mathrm{~N}$ sodium hydroxide were added to $10 \mathrm{mg}$ of each extract. Red coloration indicated the presence of cardenolides or $\alpha, \beta$-unsaturated lactones. 2002).

Testing for flavonoids: (Trease \& Evans,

Shinoda test: A volumen of 10 drops of diluted extract in methanol was added with $1 \mathrm{~mL}$ of methanol and three drops of hydrochloric acid $12 \mathrm{M}$. Formation of a red color indicated the presence of aurones and chalcones.

Pew's test: A volume of $1 \mathrm{~mL}$ of each diluted extract in methanol was added with
$2 \mathrm{mg}$ of zinc powder and 5 drops of $5 \mathrm{~N}$ hydrochloric acid. The presence of red, pink or coffee color indicated the existence of flavonones, and dihydrochalcones.

Test with $10 \%$ sodium hydroxide: A volume of $1 \mathrm{~mL}$ of diluted extract in methanol was added with three drops of sodium hydroxide $10 \%$. Formation of yellow, coffee or purple coloration indicated the presence of xanthones, flavones, chalcones and anthocyanins.

Testing for steroids and/or triterpenoids: (Tiwari et al., 2011)

Salkowski test: A volume of 10 drops of the extract dissolved in methanol was mixed with 2 $\mathrm{mL}$ of chloroform and $1 \mathrm{~mL}$ of sulfuric acid 18 $\mathrm{M}$ were added to until double phase formation. The presence of a reddish-brown color in the middle layer was indicative of steroidal ring.

Rosenthaler test: A volume of $2 \mathrm{~mL}$ of the extract dissolved in methanol was added with 3 drops of rosenthaler reagent and 2 drops of sulfuric acid $18 \mathrm{M}$. Formation of violet color in the middle layer was indicative of terpenoids.

Lieberman-Bouchard test: A volume of 2 $\mathrm{mL}$ of the extract dissolved in methanol was mixed with $1 \mathrm{~mL}$ of anhydrous acetic acid and 3 drops of sulfuric acid $18 \mathrm{M}$. After five min a blue color middle layer was indicative of sterols, but a pink, red or violet color revealed the presence of terpenoids.

Testing for quinones and anthraquinones: (Tiwari et al., 2011).

Borntraguer test: An amount of $10 \mathrm{mg}$ of each extract were dissolved in $3 \mathrm{~mL}$ of distilled water and filtrated by gravity. After filtration, three $\mathrm{mL}$ of $5 \%$ potassium hydroxide solution were added to each one. The mixture was heated to boiling for three min. Alkaline solution was allowed to cool down and then extracted with $3 \mathrm{~mL}$ of chloroform. The organic phase was separated and shaken with $2 \mathrm{~mL}$ of $5 \%$ potassium hydroxide solution. Occurrence of red color in alkaline phase indicated the presence of quinones.

Test with ammonium hydroxide: One drop of concentrated ammonium hydroxide was 
added to $10 \mathrm{mg}$ of each extract, previously dissolved in methanol. After $2 \mathrm{~min}$, formation of red colour indicated the presence of anthraquinone.

Test with sulfuric acid: One drop of concentrated sulfuric acid was added to $10 \mathrm{mg}$ of each extract dissolved in methanol. Formation of red color indicated the presence of quinones.

Testing for tannins: $100 \mathrm{mg}$ of each extract was dissolved in $10 \mathrm{~mL}$ of methanol, each methanol extract was mixed with 25 $\mathrm{mL}$ of distilled water and allowed to boil for $15 \mathrm{~min}$. Once the mixture is fresh, $0.2 \mathrm{~mL}$ of $10 \%$ sodium chloride solution were added and then filtered by gravity. The filtrate was divided into four equal portions in test tubes. A volume of 5 drops of $1 \%$ gelatin solution were added to the first portion, five drops of gelatin-salt solution $(1 \%$ gelatin $+10 \%$ salt $)$ were added to the second, four drops of $10 \%$ ferric chloride solution were added to the third, and 3 drops of $1 \%$ potassium ferricyanide solution were added to the fourth portion. Precipitation observed after addition of either second or third reagent was indicative of tannins. Those samples showing grayish colour after addition of third reagent indicated the presence of tannins with catechol or pyrogallol nuclei. Samples turning to blue colour after the fourth reagent revealed the presence of phenolic compounds (ShyamalaGowri \& Vasantha, 2010).

Testing for phenols: An amount of $10 \mathrm{mg}$ of each extract were dissolved in $1 \mathrm{~mL}$ of methanol, then $2 \mathrm{~mL}$ of distilled water was added followed by 4 drops of ferric chloride aqueous solution $10 \% \mathrm{w} / \mathrm{v}$. Formation of a blue or green color indicated the presence of phenols. 2002).

Testing for saponins: (Trease \& Evans,

Foam height test (without sodium bicarbonate): One $\mathrm{mL}$ of distilled water was added to 10 drops of the extract dissolved in methanol (20 $\mathrm{mg} \mathrm{mL}^{-1}$ ) in a test-tube, shaken vigorously to froth, then allowed to stand for 30 min. Saponin content was measured as follows: no froth (absence); froth less than $3 \mathrm{~mm}$ high (low); froth $6 \mathrm{~mm}$ high (moderate) and froth greater than $8 \mathrm{~mm}$ high (abundant).

Foam test (with sodium bicarbonate): One $\mathrm{mL}$ of distilled water and 1 drop of sodium bicarbonate saturated solution were added to 5 drops of the extract dissolved in methanol (20 mg.mL ${ }^{-1}$ ) in a test-tube and shaken vigorously during three min. Formation of honeycomb shaped foam indicated the presence of saponins.

Antioxidant activity: Free radical scavenging activity, total phenolic and total flavonoid content assays were performed in order to determine antioxidant activity on the extracts under investigation.

\section{2,2-diphenyl-1-picryl-hydrazyl (DPPH)} radical scavenging method (Goupy, Bautista, Fulcrand, \& Dangles, 2009). Different concentrations ranging between 2 to $200 \mu \mathrm{g} \mathrm{mL}^{-1}$ of each extract were added to $2.8 \mathrm{~mL}$ of DPPH solution at $6 \times 10^{-2} \mathrm{mM}$ diluted in methanol. The mixture was left in the dark at room temperature for $30 \mathrm{~min}$; then, the absorbance at $517 \mathrm{~nm}$ was measured using an UV-visible spectrophotometer (Perkin Elmer, Lambda 11). DPPH test was accomplished by triplicate; ascorbic acid at concentration between 0.4 to $2.0 \mu \mathrm{g} \mathrm{mL}^{-1}(\mathrm{Y}=36.808 \mathrm{X}-0.2649 ; \mathrm{r}=0.9964)$ was used as positive control while methanol was measured as negative reaction. The capability to scavenge the DPPH radical was calculated by using the following equation:

DPPH scavenging effect $(\%)=\left(\mathrm{A}_{1}-\mathrm{A}_{2} / \mathrm{A}_{1}\right) \times 100$

Where: $A_{1}=$ absorbance of control reaction (DPPH + methanol), $A_{2}=$ absorbance in the presence of sample (DPPH + sample). The $\mathrm{IC}_{50}$ value was defined as the concentration $(\mu \mathrm{g}$ $\mathrm{mL}^{-1}$ ) necessary to decrease the initial DPPH amount by $50 \%$.

Total phenolic content: Total phenolic content was determined by the Folin-Ciocalteu method (Škerget et al., 2005). A volume of $0.5 \mathrm{~mL}$ of each extract previously diluted 
in methanol was added to $2.5 \mathrm{~mL}$ of FolinCiocalteu reagent and left at room temperature for three min. Then, $2 \mathrm{~mL}$ of sodium carbonate $0.71 \mathrm{M}$ were added to the mixture and left in the dark for another $5 \mathrm{~min}$. Absorbance was measured at $760 \mathrm{~nm}$ using an UV-visible spectrophotometer (Perkin Elmer, Lambda 11). Gallic acid was used as positive control at concentration ranging between 2 to $16 \mu \mathrm{g}$ $\mathrm{mL}^{-1}(\mathrm{Y}=0.0632 \mathrm{X}+0.0024 ; \mathrm{r}=0.9989)$, while methanol was measured as negative reaction. Total phenolic content was determined as milligrams of Gallic acid equivalents per gram of dry extract (mg Eq AG / g Ext).

Total flavonoid content: Total flavonoid content was determined using the colorimetric test by Kim, Chun, Kim, Moon and Lee (2003). A mixture of $0.3 \mathrm{~mL}$ of $0.72 \mathrm{M}$ sodium nitrite and $0.3 \mathrm{~mL}$ of $0.75 \mathrm{M}$ aluminum chloride were added to each sample previously diluted in methanol. The mixture was left at room temperature for $5 \mathrm{~min}$. Then, $2 \mathrm{~mL}$ of $1 \mathrm{M}$ sodium hydroxide solution was also added. Distilled water was incorporated to each sample to complete a total volume of $10 \mathrm{~mL}$. After mixing each sample by using a vortex, the absorbance at $510 \mathrm{~nm}$ was measured using an UV-visible spectrophotometer (Perkin Elmer, Lambda 11).
Quercetin was used as positive control at concentration ranging between 10 to $25 \mu \mathrm{g} \mathrm{mL}-1$ $(\mathrm{Y}=0.0135 \mathrm{X}-0.0021 ; \mathrm{r}=0.9987)$. Flavonoid content was determined as milligrams of quercetin equivalent per gram of dry extract (mg Eq Q / g Ext).

Assays were carried out by triplicate and values are expressed as means of standard deviation $( \pm \mathrm{SD})$. Data was subjected to two way variance analysis (ANOVA) and significant difference between means was determined by LSD Fisher test $(\mathrm{P}<0.05)$ using Statistical Package R Core Team (2015).

\section{RESULTS}

Phytochemical screening of methanolic extracts of VB and VM was carried out using various chemical assays in order to identify either the presence or absence of secondary metabolites such as alkaloids, coumarins, phenolic compounds, flavonoids, glycosides, quinones, saponins, tannins, steroids and triterpenoids.

According to results (Table 1), anthraquinones are abundant in both species analyzed, while anthrones and quinones showed a moderate presence. Glycosides were also present in both species analyzed, while tannins

TABLE 1

Phytochemical screening of methanol extracts from $V$. baccifera and $V$. macrophylla

\begin{tabular}{|c|c|c|c|c|c|c|c|}
\hline $\begin{array}{l}\text { Secondary } \\
\text { metabolites }\end{array}$ & Test & VB & VM & $\begin{array}{l}\text { Secondary } \\
\text { metabolites }\end{array}$ & Test & VB & VM \\
\hline \multirow[t]{3}{*}{ Quinones Anthraquinones } & $\mathrm{NH}_{4} \mathrm{OH}$ conc & 3 & 3 & Tannins & $1 \%$ Gelatin & 1 & 1 \\
\hline & $\mathrm{H}_{2} \mathrm{SO}_{4 \text { conc }}$ & 2 & 2 & & Gelatin-Salt solution & 2 & 2 \\
\hline & Borntraguer & 2 & 2 & & $\mathrm{~K}_{3} \mathrm{Fe}(\mathrm{CN})_{6}$ & 1 & 1 \\
\hline \multirow[t]{2}{*}{ Glycosides } & $\mathrm{NaOH}_{\text {conc }}$ & 3 & 3 & & $\mathrm{FeCl}_{3} 10 \%$ & 2 & 2 \\
\hline & Keller Killiani & 0 & 0 & Saponins & Foam height & 2 & 1 \\
\hline Cardiotonic Glycosides & Legal & 0 & 0 & & $\mathrm{NaHCO}_{3}$ & 1 & 1 \\
\hline Steroids & Lieberman Bouchard & 2 & 3 & Alkaloids & Wagner & 0 & 0 \\
\hline \multirow[t]{2}{*}{ Terpenoids } & Rosenthaler & 1 & 1 & & Dragendorff & 0 & 0 \\
\hline & Salkowskí & 2 & 3 & & Mayer & 0 & 0 \\
\hline \multirow[t]{3}{*}{ Flavonoids } & Shinoda & 2 & 2 & Coumarins & $\mathrm{NH}_{4} \mathrm{OH}$ & 0 & 0 \\
\hline & Pew's & 3 & 2 & Mucilage & Cooling $5^{\circ} \mathrm{C}$ & 0 & 0 \\
\hline & $\mathrm{NaOH} 10 \%$ & 2 & 3 & Phenols & $\mathrm{FeCl}_{3} 5 \%, \mathrm{NaCl} 0.9 \%$ & 1 & 2 \\
\hline
\end{tabular}

VB: Vismia baccifera, VM: Vismia macrophylla. Absence: (0); low: (1); mediun (2); abundant: (3). 
only showed moderate incidence. In addition, flavones and dehydroflavones were observed abundantly in VB, while a moderate presence was detected in VM. Xanthones were observed in VB while flavonols were only detected in VM. Regarding phenol compounds, these showed a moderated presence in VM but VB only exhibited a low content of these.

Lieberman and Rosenthaler assays revealed that triterpenes were present in both species analyzed, while Salkoswky test indicated that steroids were abundant in VM but moderate in VB. Concerning saponins, the foam height test showed a major presence of these in VB, however, sodium bicarbonate assay revealed same profile for both species. Finally, alkaloids, coumarins and mucilages were not detected either in VB or VM.

Antioxidant capacity was measured by the DPPH radical scavenging assay in methanol extracts of VM and VB as well as hexane, dichloromethane, ethyl acetate and butanol extracts obtained from liquid-liquid fractionation carried out on the two Vismia species under investigation. This activity was expressed as $\mathrm{IC}_{50}$ values. According to ANOVA analysis (Table 2), applied to the three assays conducted (DPPH, Total Phenols and Flavonoids content), there is a significant difference between the diverse polar solvent extracts, as well as for the two species analyzed. The highest $\mathrm{IC}_{50}$ was observed in Hexane extract $\left(110.44 \mu \mathrm{g} \mathrm{mL}^{-1}\right.$ $\mathrm{VB} ; 104.42 \mu \mathrm{g} \mathrm{mL}^{-1} \mathrm{VM}$ ) while the lowest values were shown by methanol extracts $(5.50$ $\mu \mathrm{g} \mathrm{mL}^{-1} \mathrm{VM}$; $5.87 \mu \mathrm{g} \mathrm{mL}^{-1} \mathrm{VB}$ ); the complete data of this assay is shown in Table 2. On the other hand, $\mathrm{IC}_{50}$ value shown by $\mathrm{VM}$ was lower compared to VB, indicating that VM possesses a stronger antioxidant activity than VB.

On the other hand, Folin-Ciocalteu assay revealed a high phenol content in methanol extracts (377.52 mg Eq AG / g Ext VM; 370.67 mg Eq AG / g Ext VB) while the lowest values were observed in hexane extracts $(26.51 \mathrm{mg} \mathrm{Eq}$ AG / g Ext VM; 42.47 mg Eq AG / g Ext VB); the complete data of this analysis is described in Table 2. Moreover, flavonoids content found in the extracts were determined by the quercetin regression equation as standard calibration ( $\mathrm{Y}=0.0135 \mathrm{X}-0.0021 ; \mathrm{r}=0.9987)$. Results indicated that VB extracts contain higher concentrations of flavonoids than VM. Furthermore, VB methanol extract showed the highest concentration of flavonoids $267.07 \mathrm{mg}$ Eq Q / g Ext (Table 2). ANOVA analysis showed that methanol is the most suitable solvent for the extraction of phenol and flavonoids in this investigation.

TABLE 2

$\mathrm{IC}_{50}$, total phenols, flavonoids content and LSD Fisher average values for both species assayed

\begin{tabular}{|c|c|c|c|c|c|c|}
\hline \multirow{2}{*}{ Extracts } & \multicolumn{2}{|c|}{ DPPH IC ${ }_{50}\left(\mathrm{mg} \cdot \mathrm{mL}^{-1}\right)$} & \multicolumn{2}{|c|}{ Total phenols mg Eq AG / g Ext } & \multicolumn{2}{|c|}{ Flavonoids content mg Eq Q / g Ext } \\
\hline & VB & VM & VB & VM & VB & VM \\
\hline \multirow[t]{2}{*}{ Hexane } & $110.44 \pm 1.10$ & $104.48 \pm 5.20$ & $42.47 \pm 0.62$ & $26.51 \pm 1.98$ & $41.76 \pm 4,21$ & $40.52 \pm 5.03$ \\
\hline & \multicolumn{2}{|c|}{$* 107.46^{\mathrm{a}}$} & \multicolumn{2}{|c|}{$* 34.50^{\mathrm{e}}$} & \multicolumn{2}{|c|}{$* 41.14^{\mathrm{e}}$} \\
\hline \multirow[t]{2}{*}{ Dichloromethane } & $12.75 \pm 0.25$ & $18.40 \pm 0.22$ & $159.16 \pm 15.3$ & $161.80 \pm 12.5$ & $245.46 \pm 15,18$ & $172.01 \pm 4.16$ \\
\hline & \multicolumn{2}{|c|}{$* 15.60^{\mathrm{b}}$} & \multicolumn{2}{|c|}{$* 160.48^{\mathrm{d}}$} & \multicolumn{2}{|c|}{$* 208.73^{\text {cd }}$} \\
\hline \multirow[t]{2}{*}{ Water } & $8.49 \pm 0.20$ & $16.77 \pm 1.43$ & $157.83 \pm 4.77$ & $149.92 \pm 14.23$ & $253.18 \pm 14.00$ & $185.90 \pm 5.87$ \\
\hline & \multicolumn{2}{|c|}{$* 12.63^{c}$} & \multicolumn{2}{|c|}{$* 153.90^{\mathrm{d}}$} & \multicolumn{2}{|c|}{$* 219.54^{\mathrm{bc}}$} \\
\hline \multirow[t]{2}{*}{ Ethyl Acetate } & $7.71 \pm 0.06$ & $17.43 \pm 0.17$ & $244.46 \pm 16.25$ & $195.65 \pm 7.13$ & $251.02 \pm 26.58$ & $231.57 \pm 1.51$ \\
\hline & \multicolumn{2}{|c|}{$* 12.57^{\mathrm{c}}$} & \multicolumn{2}{|c|}{$* 220.06^{\mathrm{c}}$} & \multicolumn{2}{|c|}{$* 241.30^{\mathrm{a}}$} \\
\hline \multirow[t]{2}{*}{ Buthanol } & $10.81 \pm 0.17$ & $12.38 \pm 0.10$ & $241.17 \pm 15.42$ & $251.50 \pm 7.26$ & $242.69 \pm 16.09$ & $153.80 \pm 2.27$ \\
\hline & \multicolumn{2}{|c|}{$* 11.60^{\mathrm{c}}$} & \multicolumn{2}{|c|}{$* 246.33^{b}$} & \multicolumn{2}{|c|}{$* 198.25^{\mathrm{d}}$} \\
\hline \multirow[t]{2}{*}{ Methanol } & $5.87 \pm 0.29$ & $5.35 \pm 0.07$ & $306.21 \pm 4.25$ & $321.98 \pm 2.90$ & $267.07 \pm 11.22$ & $185.90 \pm 3.81$ \\
\hline & \multicolumn{2}{|c|}{$* 5.61^{\mathrm{d}}$} & \multicolumn{2}{|c|}{$* 314.10^{\mathrm{a}}$} & \multicolumn{2}{|c|}{$* 226.48^{\mathrm{ab}}$} \\
\hline
\end{tabular}

*Values from same column showing same letter (a-e) means that no significant differences were observed, $\alpha=0.05$. 


\section{DISCUSSION}

Previous investigations have reported anthraquinones, xanthones, anthrones, bianthrones and other related compounds in several Vismia species such as V. latifolia, V. laurentii, $V$. rubescens, V. baccifera, V. guaramirangae, $V$. guianensis, $V$. martiana, $V$. magnoliaefolia and $V$. guineensis. These classes of secondary metabolites are commonly found in Vismia genus. Furthermore, glycosides have been detected in $V$. micrantha and $V$. guineensis; flavonoids and other derivatives have been observed in $V$. parviflora, $V$. magnoliifolia, $V$. laurentii and $V$. guineensis; Phenols have also been reported for $V$. decipines, $V$. guianensis, $V$. guaramirangae, $V$. cayenensis, $V$. guineensis and $V$. baccifera. Triterpenes and saponins, have been previously isolated from $V$. parviflora, $V$. guianensis, $V$. laurentii, $V$. guaramirangae, $V$. japurensis, $V$. martiana, $V$. Rubescens, $V$. baccifera, $V$. cayenensis and $V$. magnoliifolia (Hussain et al., 2012); results observed in this investigation are in accordance to these statements. Finally, alkaloids, coumarins and mucilages were not detected either in VB or VM. These analyses confirm previous investigations, where none of these secondary metabolites has been reported (Tiwari et al., 2011; Vizcaya et al., 2012).

In relation to antioxidant capacity it is worth to remember that, DPPH is a stable free radical that may be able to accept an electron or hydrogen radical to become a stable diamagnetic molecule. Interaction of an antioxidant molecule with DPPH lead to the transfer of an electron or hydrogen atom to it, thus neutralizing its free radical character and convert it to 1-1,diphenyl-2-picryl hydrazine. The reduction capacity of DPPH radical is determined by the decrease in its absorbance at $517 \mathrm{~nm}$ induced by antioxidant molecules and it is visually noticeable as a change in color from purple to yellow (Raghavendra, Madhusudhana, Raghuveer, Sudharshan, \& Siva, 2013). In this type of assays the number of DPPH molecules that are reduced seems to be related to the number of available hydroxyl groups (Brands-Williams,
Cuvelier, \& Berset, 1995). Thus, methanol extracts composed by polar molecules with abundant free hydroxyl groups such as flavonoids, phenols, tannins, among others may exhibit a strong scavenging activity.

In the present investigation, antioxidant capacity was measured by the DPPH radical scavenging assay and was expressed as $\mathrm{IC}_{50}$ values. Bearing in mind that lower $\mathrm{IC}_{50}$ values suggest higher scavenging activity and comparing these results to ascorbic acid $\mathrm{IC}_{50} 1.37$ $\mu \mathrm{g} \mathrm{mL} \mathrm{m}^{-1}$ is possible to affirm that methanol extracts of both species analyzed exhibited a significant scavenging potential. Previous investigations conducted on different polar solvent extracts like petroleum ether, ethyl acetate and methanol, obtained from $V$. baccifera ssp. ferruginea and $V$. guianensis collected from Arvi Regional Park (Antioquia, Colombia), revealed that ethyl acetate possesses the strongest scavenging activity showing $\mathrm{IC}_{50}$ values of $3.72 \mu \mathrm{g} \mathrm{mL}^{-1}$ and $5.86 \mu \mathrm{g} \mathrm{mL}^{-1}$ for $V$. guianensis while ethyl acetate extract from $V$. baccifera spp. ferruginea showed concentrations of $4.46 \mu \mathrm{g} \mathrm{mL}^{-1}$ and $4.16 \mu \mathrm{g} \mathrm{mL}^{-1}$ in DPPH and ABTS assays, respectively (Álvarez et al., 2008). Ethanol extract of $V$. macrophylla collected from Chocó, Colombia also showed antioxidant activity, researchers suggested a correlation between this activity and phenol compounds present in the extract (Gutiérrez, Pino, \& Cuesta, 2011). Likewise a recent investigation revealed that stem bark and flower extract of Vismia cauliflora have antioxidant activity by preventing oxidative burst in neutrophils and oxidative damage in erythrocytes (Ribeiro et al., 2015). On the other hand, FolinCiocalteu assay revealed a high phenol content in methanol extracts while the lowest values were observed in hexane extracts. Results obtained in this investigation proved a relationship between the antioxidant activity, total phenol and flavonoids content of the extracts analyzed. Those samples with higher phenolic concentration showed higher antioxidant activity as well. The present investigation revealed that methanol extracts of Vismia macrophylla and Vismia baccifera have strong antioxidant 
activity highlighting these plant species as a promising source for medicine purposes.

\section{ACKNOWLEDGMENTS}

Authors wish to acknowledge Alirica Suarez who provided the flavonoid quercetin; Claudia Plaza and Ismer Bracho for the DPPH and gallic acid donation.

\section{RESUMEN}

Actividad antioxidante in vitro y análisis fitoquímico cualitativo de dos especies de Vismia (Hypericaceae) recolectadas en Los Andes, Venezuela. El género Vismia esta distribuido principalmente en las regiones tropicales y subtropicales de Centro, Sur América y algunas zonas de África. De acuerdo a reportes previos, el potencial antioxidante de las especies de Vismia puede estar relacionado con antronas, antraquinonas, flavonoides y derivados fenólicos biosintetizados por estas plantas. En la presente investigación, el tamizaje fitoquímico de los extractos metanólicos de Vismia baccifera (VB) de Mérida-Venezuela y Vismia macrophylla (VM) de Táchira-Venezuela realizado con diferentes ensayos químicos reveló abundante presencia de antraquinonas en ambas especies analizadas. Glucósidos también estuvieron presentes mientras que flavonas y dehidroflavonas fueron observados abundantemente en VB pero con presencia moderada en VM. Triterpenos y esteroides también fueron detectados mostrando ser abundantes en VM y moderados en VB. Por otro lado, la actividad antioxidante determinada por el método DPPH reveló que VM posee actividad antioxidante más fuerte que VB con un $\mathrm{IC}_{50}$ de $5.50 \mu \mathrm{g} \mathrm{mL}^{-1}$. El ensayo del contenido de fenoles y flavonoides realizado con los métodos de Folin-Ciocalteu y test colorimétrico también demostró que los extractos metanólicos de ambas especies contienen altas concentraciones de estos metabolitos. En este estudio se observó una relación entre la actividad antioxidante, el contenido de fenoles y de flavonoides en los extractos analizados ya que las muestras que presentaron concentraciones más altas de fenoles y flavonoides también mostraron una mayor actividad antioxidante.

Palabras clave: actividad antioxidante, DPPH, fenoles totales, contenido de flavonoides, análisis fitoquímico cualitativo, Vismia baccifera, Vismia macrophylla.

\section{REFERENCES}

Álvarez, E., Jiménez, O., Posada, C., Rojano, B., Gil, J., García, C., \& Durango, D. (2008). Actividad antioxidante y contenido fenólico de los extractos provenientes de las bayas de dos especies del género Vismia (Guttiferae). VITAE, 15, 165-172.

Baydar, N. G., Özkan, G., \& Yasar, S. (2007). Evaluation of the antiradical and antioxidant potential of grape extracts. Food Control, 18, 1131-1136.

Botta, B., Delle-Monache, G., Delle-Monache, F., MariniBettolo, G. B., \& Menichini, F. (1986). Vismione H and prenylated xanthones from Vismia guineensis. Phytochemistry, 25, 1217-1219.

Brands-Williams, W., Cuvelier, M. E., \& Berset, C. (1995). Use of a free radical method to evaluated antioxidant activity. LWT- Food Science and Technology, 28, 25-30.

Fuller, R., Westergaard, C., Collins, J., Cardellina, J., \& Boyd, M. (1999). Vismiaphenones D-G from Vismia cayennensis. Journal of Natural Products, 62, 67-69.

Goupy, P., Bautista, A., Fulcrand, H., \& Dangles, O. (2009). Antioxidant activity of wine pigments derived from anthocyanins: Hydrogen transfer reactions to the DPPH radical and inhibition of the heme-induced peroxidation of linoleic acid. Journal of Agricultural and Food Chemistry, 57, 5762-5770.

Gutiérrez, M., A., Pino, B. N., \& Cuesta, L. J. A. (2011). Actividad antioxidante y contenido total de fenoles de varios extractos etanólicos de plantas medicinales. Investigación, Biodiversidad y Desarrollo, 30(1), 66-73.

Hossain, M. A., \& Shah, M. D. (2015). A study on the total phenols content and antioxidant activity of essential oil and different solvent extracts of endemic plant Merremia borneensis. Arabian Journal of Chemistry, 8, 66-71.

Hussain, H., Hussain, J., Al-Harrasi, A., Saleem, M., Green, I. R., van Ree, T., \& Ghulam, A. (2012). Chemistry and biology of genus Vismia. Pharmaceutical Biology, 50, 1448-1462.

Kim, D. O., Chun, O. K., Kim, Y. J., Moon, H. Y., \& Lee, C. (2003). Quantification of phenolics and their antioxidant capacity in fresh plums. Journal of Agricultural and Food Chemistry, 51, 6509-6515.

Lizcano, L. J., Siles, M., Trepiana, J., Hernández, L., Navarro, R., Ruiz-Larrea, B., \& Ruiz-Sanz, J. I. (2015). Piper and Vismia species from Colombian Amazonia differentially affect cell proliferation of hepatocarcinoma cells. Nutrients, 7, 179-195.

Lizcano, L. J., Fadil-Bakkali, M., Ruiz-Larrea, B., \& Ruiz-Sanz, J. I. (2010). Antioxidant activity and polyphenol content of aqueous extracts from Colombian Amazonian plants with medicinal use. Food Chemistry, 119(4), 1566-1570. 
Nagem, T., \& de Oliveira, F. (1997). Xanthones and other constituents of Vismia parviflora. Journal of the Brazilian Chemical Society, 8, 505-508.

Parajuli, S., Pun, N. T., Parajuli, Sh., \& Jamarkattel-Pandit, N. (2012). Antioxidant activity, total phenol and flavonoid contents in some selected medicinal plants of Nepal. JHAS, 2, 27-31.

R Core Team. (2015). R: A language and environment for statistical computing. R Foundation for Statistical Computing, Vienna, Austria. Retrieved from http:// www.R-project.org/.

Raghavendra, M., Madhusudhana, A., Raghuveer, P., Sudharshan, A., \& Siva, L. (2013). Comparative studies on the in vitro antioxidant properties of methanolic leafy extracts from six edible leafy vegetables of India. Asian Journal of Pharmaceutical and Clinical Research, 6, 96-99.

Ribeiro, A. B., Berto, A., Ribeiro, D., Freitas, M., Chisté, R. C., Visentainer, J. V., \& Fernandes, E. (2015). Stem bark and flower extracts of Vismia cauliflora are highly effective antioxidants to human blood cells by preventing oxidative burst in neutrophils and oxidative damage in erythrocytes. Pharmaceutical Biology, 53(11), 1691-1698.

Sarabjot, K., \& Poonam, M. (2014). Study of total phenolic and flavonoid content, antioxidant activity and antimicrobial properties of medicinal plants. Journal of Microbiology \& Experimentation, 1, 1-6.
Shah, M. D., \& Hossain, M. A. (2014). Total flavonoids content and biochemical screening of the leaves of tropical endemic medicinal plant Merremia borneensis. Arabian Journal of Chemistry, 7, 1034-1038.

Shyamala-Gowri, S., \& Vasantha, K. (2010). Phytochemical screening and antibacterial activity of Syzygium cumini (L.) (Myrtaceae) leaves extracts. International Journal of PharmTech Research, 2, 1569-1573.

Škerget, M., Kotnik, P., Hadolin, M., Hraš, A. R., Simonič, M., \& Knez, Ž. (2005). Phenols, proanthocyanidins, flavones and flavonols in some plant materials and their antioxidant activities. Food Chemistry, 89, 191-198.

Tepe, B., \& Sokmen, A. (2007). Screening of the antioxidative properties and total phenolic contents of three endemic Tanacetum subspecies from Turkish flora. Bioresource Technology, 98, 3076-3079.

Tiwari, P., Kumar, B., Kaur, M., Kaur, G., \& Kaur, H. (2011). Phytochemical screening and extraction: A Review. Internationale Pharmaceutica Sciencia, 1, 98-106.

Trease, G. E., \& Evans, W. C. (2002). Pharmacognosy. England: Ed. Saunders Publishers.

Vizcaya, M., Morales, A., Rojas, J., \& Nuñez, R. (2012). Revisión bibliográfica sobre la composición química y actividades farmacológicas del género Vismia (Guttiferae). Boletín Latinoamericano y del Caribe de Plantas Medicinales y Aromáticas, 11(1), 12-34. 
